\title{
Acute cyanosis in a child after percutaneous placement of a peritoneal dialysis catheter: question
}

\author{
Murat Anil • Alkan Bal • Ayse Berna Anil • \\ Onder Yavascan • Orhan Deniz Kara • Nejat Aksu
}

Received: 17 September 2008 /Revised: 2 December 2008 / Accepted: 3 December 2008 / Published online: 27 January 2009

(C) IPNA 2009

\section{Case summary}

A 6-year-old girl with end-stage renal disease due to focal segmental glomerulosclerosis was admitted for percutaneous placement of a peritoneal dialysis catheter. The physical examination before the procedure revealed a child with a pale appearance and a weight of $16 \mathrm{~kg}$ (25th-50th percentile) and a height of $95 \mathrm{~cm}(<3 \mathrm{rd}$ percentile). Her vital signs were in normal range. Baseline laboratory test values were as follows: white blood cells (WBCs) 14,700/ $\mu 1$ (55\% neutrophils); hemoglobin $(\mathrm{Hb}) 7.4 \mathrm{~g} / \mathrm{dl}$; hematocrit

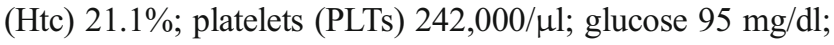
urea $256 \mathrm{mg} / \mathrm{dl}$; creatinine $3.8 \mathrm{mg} / \mathrm{dl}$; aspartate aminotransferase (AST) $38 \mathrm{U} / 1$; alanine aminotransferase (ALT) $27 \mathrm{U} / 1$; sodium $\left(\mathrm{Na}^{+}\right) 138 \mathrm{mEq} / \mathrm{l}$; potassium $\left(\mathrm{K}^{+}\right) 4.4 \mathrm{mEq} / \mathrm{l}$. The results of clotting tests were normal. Arterial blood gas

The answer to this question can be found at http://dx.doi.org/10.1007/ s00467-008-1109-2.

M. Anil $(\bowtie) \cdot$ A. Bal $\cdot$ A. B. Anil $\cdot$ O. Yavascan $\cdot$ O. D. Kara Department of Pediatrics,

Tepecik Training and Research Hospital,

Izmir, Turkey

e-mail: muratanil1969@hotmail.com

N. Aksu

Pediatric Nephrology, Department of Pediatrics,

Tepecik Training and Research Hospital,

Izmir, Turkey

Present address:

M. Anil

Mehmet Emin Gürkan Caddesi,

Akasya apt. No: 10 Daire: 5,

35410 Gaziemir, İzmir, Turkey analysis in room air showed a $\mathrm{pH}$ of 7.34, carbon dioxide partial pressure $\left(\mathrm{pCO}_{2}\right) 40.5 \mathrm{mmHg}$, oxygen partial pressure $\left(\mathrm{pO}_{2}\right) 96 \mathrm{mmHg}$, and bicarbonate $\left(\mathrm{HCO}_{3}^{-}\right)$ $20.8 \mathrm{mEq} / \mathrm{l}$. Just prior to the procedure, local anesthesia with $10 \mathrm{ml}$ prilocaine $(20 \mathrm{mg} / \mathrm{ml})$ was induced at the linea alba, $2 \mathrm{~cm}$ below the umbilicus. During the procedure, the patient's oxygen saturation was above 94\%, shown by pulse oximetry. The peritoneal dialysis (PD) catheter was inserted successfully. Two hours later the patient developed central and peripheral cyanosis, without significant respiratory distress. Her body temperature was $37^{\circ} \mathrm{C}$; heart rate 98 beats/min; respiratory rate 24 breaths $/ \mathrm{min}$; blood pressure $90 / 60 \mathrm{mmHg}$; oxygen saturation $76 \%$ (measured by peripheral transcutaneous pulse oximetry) in room air. Findings from cardiac and pulmonary examination were unremarkable. Although a non-rebreather mask was immediately placed, no improvement of the child's color and oxygen saturation was observed. Echocardiography and chest X-ray findings were normal. Arterial blood gas analysis revealed that $\mathrm{pH}, \mathrm{pO}_{2}$ and $\mathrm{pCO}_{2}$ were 7.35, $97 \mathrm{mmHg}$ and $27 \mathrm{mmHg}$, respectively. Her hemoglobin level was $7.6 \mathrm{~g} / \mathrm{dl}$. Central cyanosis and low oxygen saturation in conjunction with normal arterial $\mathrm{pO}_{2}$ level persisted. Her glucose-6-phosphate dehydrogenase (G6PD) level was normal $(4.2 \mathrm{U} / \mathrm{g} \mathrm{Hb})$.

\section{Questions}

1. Which diseases should be considered in the differential diagnosis of this child with abrupt-onset cyanosis?

2. Which diagnostic test confirms your diagnosis?

3. How is this condition treated? 